towns of North Bihar and Monghyr, especially Darbhanga, Muzaffarpur and Motihari. Outside the towns, the principal effects are broken and obliterated roads, the collapse of bridges, floods and great fissures in the ground, from which mud, sand and water have issued, covering fields and crops with a devastating slimy deposit. The central area contains more than 300 square miles under sugar-cane. Though much of this has been saved, nearly all the sugar-mills have been destroyed. The chief difficulties at present are the supply of drinking water and the prevention of epidemics in towns and villages.

\section{Palestinian Remains at the British Museum}

THE next special exhibition of prehistoric material at the British Museum will be opened on February 5 and will remain open for two or three months. Two cases at the head of the main staircase, in the Department of British and Mediæval Antiquities, will be devoted to a display of a typical series from stratified caves near Mount Carmel, where excavations have been carried out by the British School of Archæology in Jerusalem and the American School of Prehistoric Research, with Miss D. A. E. Garrod as field-director. Skeletal remains of palæolithic man will be shown (Palceanthropus palestinensis), and a sequence of implements from an early phase of the Palæolithic to Mesolithic, the latter being known as Natufian. A special feature of the excavations is the blend of St. Acheul and Le Moustier elements for a period; and a long succession of Aurignac types gives place to the post-palæolithic with a different and peculiar fauna. The abundant yield is incidentally useful for its similarities and contrasts to the better-known European industries, and special interest is attached to the beginnings of agriculture in Palestine.

\section{Velocity of Light}

As was to be expected, the announcement which appeared in the press last summer (NATURE, 130, 25, July 2; 277, Aug. 20, 1932) to the effect that the latest experiments indicated a periodic variation in the velocity of light, has been construed in the sense that some seasonal instrumental error was at work. Science Service now issues an official confirmation of this view, given by the Mount Wilson authorities. The report adds that the best value for the velocity of light is now $299,774 \mathrm{~km}$. $/ \mathrm{sec}$. and that further analysis is only likely to change the last figure by one or two units. The present investigation of the velocity of light is being carried out by Pease and Pearson, who are continuing Michelson's work and using the well-known rotating mirror method. It will be remembered that when Michelson used long base lines between mountain peaks, he found that irregularities in atmospheric refraction-the astronomer's "bad seeing"-interfered with the definition of the reflected image. The base is now in vacuo, in a pipe line a mile in length. To obtain more accurate results, it would be necessary to build a more stable pipe line, use quartz mirrors and employ elaborate timing devices.

\section{Projected Electric Railways in Pàlestine}

Is the Electrician of January 5 a description is given of a projected railway system for Palestine radiating from Jerusalem. Four new lines will radiate from a terminus at Jerusalem located outside the city on the northern side and east of the Damascus Gate. Possibly recent economic developments in the country, the most important of which is the new harbour at Haifa on the Mediterranean, has tended to emphasise the isolated position of Jerusalem so far as railway facilities are concerned. The northern line is to be 67 miles long, starting from the Jerusalem terminus, going through the Jordan valley, where the line descends to 500 feet below the Mediterranean level, finally getting to Tul Keram Junction on the main Haifa-Cairo line. The eastern line (55 miles) would run from the terminus, crossing the River Jordan, passing through the Kalaat ez Zerka Station on the Hejaz railway to Ammam, the capital of Transjordan and the headquarters of the British Government's High Commissioner. The southern railway (50 miles) would run through Hebron to Beersheba. Finally, there would be a line (18 miles) from Wadi Fara on the northern line through Jericho to the potash works on the shore of the Dead Sea. It is proposed to build a power station and a reservoir in Transjordan and another on the eastern shore of the Dead Sea to provide the electric current for operating the four railways. The latter station would be necessary if an extension railway to the Red Sea should materialise. Some years ago this project was discussed, the terminals of the line being Haifa and the ancient port of Akaba on the Red Sea. This would place Jerusalem on a direct sea-tosea railway from the Mediterranean to the Red Sea. Possibly it might revive the ancient and prosperous traffic route from the Red Sea to the Levant of the times of Solomon and the Romans.

\section{Transmission of Power by High Tension Direct Current}

AT the second World Power Conference held at Berlin in 1930, much consideration was given to international schemes for transmitting large amounts of power by high tension direct current. The most ambitious of these schemes was to transmit one million kilowatts from the western fiords of Norway at a pressure of 500 kilovolts across Sweden and Denmark to the industrial regions in Westphalia, Germany. The great advantage of utilising power from the western fiords is that a uniform output of power all the year round could be obtained. It was proposed that the line should pass through Göteborg and Copenhagen to Hamburg, small amounts of power being tapped off at the two former cities, but the great bulk being delivered to Hamburg for distribution in the German networks. In a paper read to the Institution of Electrical Engineers on January 18, H. Rissik discussed the engineering aspects of the problem. He pointed out that with the same overhead lines, much larger currents can be used with direct than with alternating currents and the difficulties of working are much less with the former than with the latter. On the other hand, 